\title{
Sacredness as an Underlying Value of Cultural Heritage Law in Europe
}

\section{Theodosios Tsivolas}

\section{(2) OpenEdition}

\section{Journals}

Electronic version

URL: http://journals.openedition.org/rdr/810

DOI: $10.4000 /$ rdr.810

ISSN: 2534-7462

\section{Publisher}

Presses universitaires de Strasbourg

Printed version

Date of publication: 3 May 2017

Number of pages: $15-28$

ISBN: 978-2-86820-973-3

ISSN: 2493-8637

\section{Electronic reference}

Theodosios Tsivolas, « Sacredness as an Underlying Value of Cultural Heritage Law in Europe », Revue du droit des religions [Online], 3 | 2017, Online since 03 February 2020, connection on 21 November 2020. URL : http://journals.openedition.org/rdr/810 ; DOI : https://doi.org/10.4000/rdr.810

\section{(c) (7) (울}

La revue du droit des religions est mise à disposition selon les termes de la Creative Commons Attribution - Pas d'Utilisation Commerciale 4.0 International - CC BY-NC 4.0. 


\section{SACREDNESS AS AN UNDERLYING VALUE OF CULTURAL HERITAGE LAW IN EUROPE}

\section{Theodosios TSIVOLAS}

University of Athens

\section{RÉSUMÉ}

Les différents instruments juridiques présentés ici révèlent que la « sacralité » est une notion relativement ambiguë. Les origines socioculturelles de cette notion sont explorées dans un premier temps, puis il est donné un aperçu de l'histoire du droit européen sur la protection du patrimoine religieux. La notion de sacralité est prise en compte par le droit de l'UE, notamment en ce qui concerne la protection du patrimoine culturel «d'importance européenne », ainsi que par les différentes législations nationales relatives au patrimoine culturel. En conclusion, l'étude introduit le concept de res mixtae qui constitue la base juridique nécessaire à la compréhension et à l'encadrement juridique des divers aspects de la sacralité proprement dite, attribut commun d'une richesse culturelle européenne partagée.

\section{ABstract}

As it is illustrated in the various legal instruments presented here, "sacredness" is a rather ambiguous notion per se. Therefore, at first, the socio-cultural origins of the subject matter are explored, followed by an overview of the European legal history on the protection of religious heritage. Afterwards, the notion of sacredness is being examined through the particular current EU legislation regarding the protection of cultural patrimony "of European significance", as well as through the various national legislative patterns of cultural heritage law. In conclusion, the study introduces the term of res mixtae; the latter provides the necessary legal foundation for the proper understanding and regulating the various aspects of sacredness, as a common attribute of a shared European cultural wealth. 


\section{INTRODUCTORY REMARKS}

According to the Roman - and later Byzantine - law, things sacred, religious, and holy, were exempted from commerce, and held to be the property of no one. "Temples, churches, altarpieces, communion cups, and whatever was consecrated according to the forms prescribed by law, were held sacred, and could not be applied to profane uses". ${ }^{1}$ These sacred assets, which were considered to be of "divine jurisdiction" (res divini iuris), comprised in fact three subcategories: the res sacrae, the res religiosae and the res sanctae. ${ }^{2}$ Of course, nowadays the relevant taxonomy may seem rather obselete. Nevertheless, even today, especially in cases of living heritage assets such as functional religious edifices and sacramental objects, i.e. assets which are still devoted to active religious purposes, the notion of "sacredness" may prove to be of importance, especially within the ambit of cultural heritage law.

Notwithstanding the above, any attempt by any scholar (let alone a jurist) to define the notion of "sacredness", even at its most primary spatial or geographical features, constitutes an arduous and complex task, that entails several interpretative and methodological ambiguities. ${ }^{3}$ Moreover, it is not the purpose nor the intention of this study to provide an overview of the scholarly discourse on the "idea of the holy" 4 or the "ambivalence of the sacred" 5 by displaying the great array of pertinent theological, anthropological and sociological disciplines, ${ }^{6}$ nor to elaborate on the relations between "the law and the sacred" in general. ${ }^{7}$ On the contrary, the focus of this analysis will be on the legal gravity of "sacredness" in connection with the current European legislative framework on the protection of cultural heritage, at both the national and international levels. Nevertheless, as we can always improve

1. Mackenzie T., Studies in Roman Law, with Comparative Views of the Laws of France, England, and Scotland, Edinburgh, W. Blackwood \& Sons, 1862, p. 163.

2. See among others MAinusCH R., Die öffentlichen Sachen der Religions - und Weltanschauungsgemeinschaften: Begründung und Konsequenzen ihres verfassungsrechtlichen Status, Tübingen, Mohr Siebeck, 1995, p. 8.

3. See Benzo A., "Towards a Definition of Sacred Places: Introductory Remarks", in FerRari S., Benzo A. (eds), Between Cultural Diversity and Common Heritage: Legal and Religious Perspectives on the Sacred Places of the Mediterranean, Farnham, Ashgate, 2014, p. 17-23.

4. Отто R., The Idea of the Holy, Oxford University Press, 1958.

5. Eliade M., Patterns in Comparative Religion, New York, Sheed \& Ward, 1958, p. 384.

6. Idinopulos T., Yonan E. (eds), The Sacred and its Scholars: Comparative Methodologies for the Study of Primary Religious Data, Leiden, Brill, 1996.

7. See Sarat A., Douglas L., Umphrey M.M., Law and the Sacred, Stanford University Press, 2007. 
our understanding of law by referring to other fields of knowledge, ${ }^{8}$ when a subject of legal interest touches upon many interrelated areas of the academia, the law should be conversant with the neighbouring disciplines as well. In that respect, an effective legal study of the notion of "sacredness" (and of "sacred space" for that matter) should be consistent with a coherent interdisciplinary approach, especially in view of the fact that "in the last two decades or so a range of topics related to secular and religious attitudes to sacred space and sites have been receiving increasing attention and varied, sometimes contradictory, treatment in legal, theological, anthropological and sociological analyses and debates". ${ }^{9}$ Therefore, before entering the realm of present-day jurisprudence, it seems appropriate to begin with the sociocultural foundations of the legal concept of "sacredness" (always in relation to its spatiality), ${ }^{10}$ and afterwards provide, in retrospect, an historical overview of the relevant protection provided by law, within the European continent.

\section{THE VAGUE CONCEPT OF "SPATIAL SACREDNESS"}

In a famous essay, based on a lecture given in 1967, Michel Foucault contested the traditional understanding of space, by establishing the concept of "heterotopias": these unique counter-sites, in contrast to utopias, constitute actual places "outside of all places, even though it may be possible to indicate their location in reality". ${ }^{11}$ This postmodern approach evokes the theoretical theme of "absolute spaces"; the latter, according to Henri Lefebvre,

8. Dworkin R., "Law as interpretation", Critical Inquiry, Vol. 9, N. 1, 1982, p. 179-200.

9. Stoyanov Y., "The Sacred Spaces and Sites of the Mediterranean in Contemporary Theological, Anthropological and Sociological Approaches and Debates", in Ferrari S., Benzo A. (eds), op. cit., p. 25-36.

10. The critical analysis of the relation between religion and spatiality began, in essence, with Durkheim's considerations on the notion of "totem", i.e. a location transformed into sacred space. However, the development and application of a systematic spatial analysis for religion has evolved since the mid-1980s, following the writings and ideas of influential intellectuals such as W. Benjamin, M. Foucault, H. Lefebvre and M. de Certeau (for an overview see Crang M., Thrift N. (eds), Thinking Space, London, Routledge, 2000). As it has been cleverly pointed out by Foucault: "L'époque actuelle serait peut-être plutôt l'époque de l'espace". Besides, from a legal viewpoint, the concept of "space" - referring to a long tradition of spatial thinking throughout different disciplines - (rather than the concept of "time") makes possible a dynamic description of contemporary laws on cultural heritage, and also provides a conceptual tool to explore the "intangible" features of the same heritage (see Müller-Mall S., Legal Spaces: Towards a Topological Thinking of Law, Berlin, Springer, 2013).

11. Foucault M., « Des espaces autres », Architecture, Mouvement, Continuité, n 5, oct. 1984, p. $46-49$. 
appear as spatial fragments imbued with transcendent and sacred qualities that create a non-homogenous space. ${ }^{12}$

The paradox, however, is that the aforementioned locations (e.g. temples, mausoleums, shrines, monastic sanctuaries or even natural monuments), whether to be defined as "heterotopias" or "absolute spaces", albeit being "privileged or distinguished in one way or another", ${ }^{13}$ continue to be a part of our natural and cultural environment. ${ }^{14}$ This particular "paradox" bears an interesting resemblance to another, quite similar contradiction, already emphasized by Mircea Eliade in his seminal work on the concept of sacredness, ${ }^{15}$ as part of his innovative research on the concept of "hierophanies", ${ }^{16}$ i.e. manifestations of sacred realities: "By manifesting the sacred, any object becomes something else, yet it continues to remain itself, for it continues to participate in its surrounding cosmic milieu. A sacred stone remains a stone [...] but for those to whom a stone reveals itself as sacred, its immediate reality is transmuted into a supernatural reality". ${ }^{17}$

As it is well known, the aforementioned dichotomy (between the sacred and the profane), which evokes an analogous bipolar distinction in relation to spatiality between the private and the public, ${ }^{18}$ is an idea originally posited by Émile Durkheim, also in conjunction with his classical theory on "sacred things", that is, things set apart and forbidden, whose function is to be radically different from the norm. ${ }^{19}$ In the same vein, the modern scholar Jonathan Z. Smith has clarified that things become "sacred" because they are identified with and used in the places where ritual is enacted. In his own words: "Ritual is not an expression of or a response to the "sacred"; rather, something [...] is made sacred by ritual". ${ }^{20}$

12. Lefebvre H., The Production of Space, Oxford, Blackwell, 1991, p. 23.

13. Ibid., p. 240.

14. Particularly in relation to the natural environment, see BURTON L., Worship and Wilderness. Culture, Religion, and Law in Public Lands Management, University of Wisconsin Press, 2002.

15. Eliade M., The Sacred and the Profane: the Nature of Religion, Boston, Houghton Mifflin Harcourt, 1959.

16. Ibid., p. 11.

17. Ibid., p. 12 .

18. Regarding the debate on the public/private dichotomy, see for instance: ForNEROD A., "The Places of Worship in France and the Public/Private Divide", in Ferrari S., PastoRELli S. (eds), Religion in Public Spaces: A European Perspective, Farnham, Ashgate, 2012, p. 323-336.

19. DuRkheim É., The Elementary Forms of the Religious Life, translated by Cosman C., Oxford University Press, 2001.

20. Sмiтн J. Z., To Take Place: Toward Theory in Ritual, University of Chicago Press, 1992, p. 106. 
Indeed, the role of ritual (as an act of sacralisation) is crucial in creating meaningful places and objects, as well as in marking out a sphere of difference and thus producing the "sacred". ${ }^{21}$ In fact, the evolution and development of religious rituals and rites has always been firmly associated with the profound human need for artistic expression and creativity. In other words, there has always been a close link between the eternal "pivoting of the sacred" 22 and the corresponding human need for "orchestrating" the cultural topography. ${ }^{23}$

Needless to say, all the aforementioned sophisticated remarks are insufficient to produce a clear-cut and unequivocal legal definition of the subject in question. ${ }^{24}$ On the contrary, they illustrate the philosophical challenge posed here by vagueness. Nevertheless, a similar state of affairs exists also in jurisprudence, where vague concepts are, as a matter of fact, a constant topic of discussion, especially in blanket clauses such as "good faith" or "public morals". ${ }^{25}$ Likewise, the ambiguity of the concept of "sacredness", and that of "sacred spaces" in particular, is noticeable, for example, at the international level, among the various "quasi-legal" documents concerning the protection of religious cultural heritage. A most recent document (issued in February, 2016) drafted thereof under the auspices of the UNESCO's Initiative on Heritage of Religious Interest, seeks, for instance, to indicate heritage assets of outstanding universal value, which "cannot be reduced to [their] material expressions, without reference to [their] particular ontology" and "associated sacred value". ${ }^{26}$ Similar wording can be also found in other soft-law documents, such as the Principles and Guidelines for the Management of Sacred Natural Sites Located in Legally Recognised Protected Areas, issued in 2008 by the International Union for Conservation of Nature, ${ }^{27}$ or

21. Knott K., The Location of Religion: A Spatial Analysis, London, Routledge, 2015, p. 102.

22. Van Gennep A., The Rites of Passage, University of Chicago Press, 2011 (1960), p. 12.

23. Ivakhiv A., "Orchestrating Sacred Space: Beyond the Social Construction of Nature", Ecotheology, N. 8.1, 2003, p. 11-29; see Bell C., Ritual Theory, Ritual Practice, Oxford University Press, p. 74.

24. See Ferrari S., "Introduction: The Legal Protection of the Sacred Places of the Mediterranean", in Ferrari S., Benzo A. (eds), op. cit., p. 1.

25. Simonnæes I., "Vague Legal Concepts. A Contradictio in Adjecto?", in Antia B. E. (ed.), Indeterminacy in Terminology and LSP: Studies in Honour of Heribert Picht, Amsterdam, J. Benjamins, 2007, p. 119-134.

26. Final Document of Conclusions and Recommendations: Thematic Expert Consultation meeting on sustainable management of the World Heritage properties of religious interest, focused on Mediterranean and South-Eastern Europe (2016), UNESCO Headquarters, 16-18 Febr. 2016, p. 4: http://whc.unesco.org/en/events/ [accessed on Jan. 13, 2017].

27. See https://cmsdata. iucn.org/downloads/pa_guidelines_016_sacred_natural_sites.pdf [accessed on Jan. 13, 2017]. 
the Universal Code on Holy Sites, which, since its issuance in 2009, has been endorsed by various interfaith networks and religious communities. ${ }^{28}$

In any case, leaving the various contemporary international instruments and guidelines aside, the roots of "spatial sacredness" could be traced back to the written sources of European legal history.

\section{PROTECTING THE SACRED HERITAGE: A EUROPEAN RETROSPECT}

One of the earliest legal texts relating to the protection and preservation of sacredness as an integral part of the religious built environment in Europe can be found in the $6^{\text {th }}$ century fundamental jurisprudence of Corpus Juris Civilis. According to the provisions of Justinian's Digesta, where "a temple has once been made sacred, the place still remains so, even after the edifice has been demolished". ${ }^{29}$ This notion of "sacred soil", ${ }^{30}$ which is fundamental also for the interpretation of the ancient Greek custom of religious asylum, ${ }^{31}$ sheds some light on the attitude towards temples and other sacred edifices previously belonging to opposing cults, amidst the religious conflicts of the Late Antiquity and the early Middle Ages. One could certainly argue that, throughout this period of transition, from the pagan era to the Christian epoch, cultural religious symbols of the past were dealt, in many instances, with aggression and hostility. However, the anti-pagan legislation of the $4^{\text {th }}$ and early $5^{\text {th }}$ centuries allowed temples to be opened "for the common use of the people" with the exception of the performance of sacrifices. ${ }^{32}$

During the Middle Ages, even if the primary incentive for the preservation of venerated Christian buildings and artifacts, due to their devotional character, remained the element of sacredness, ${ }^{33}$ their artistic value as revered cultural assets, was gradually acknowledged at the legislative level. This

28. See http://www.kas.de/wf/doc/kas_12037-1442-1-30.pdf?140204080404 [accessed on Jan. 13, 2017].

29. Digesta, I. VIII.6.3.

30. Buckland W. W., A Text Book of Roman Law from Augustus to Justinian, Cambridge University Press, 1921, p. 185, fn 1.

31. Pedley J., Sanctuaries and the Sacred in the Ancient Greek World, Cambridge University Press, 2005.

32. Makrides V., Hellenic Temples and Christian Churches. A Concise History of the Religious Cultures of Greece from Antiquity to the Present, New York University Press, 2009, p. 1261.

33. Odendahl K., Kulturgüterschutz: Entwicklung, Struktur und Dogmatik eines ebenenübergreifenden Normensystems, Tübingen, Mohr Siebeck, 2005, p. 9. 
is best reflected in Charlemagne's administrative legislation relating to the architectural preservation and improvement of sacred edifices. ${ }^{34}$ Besides, the majority of the canonistic documents of the Byzantine era, called Typika, dated between the $9^{\text {th }}$ and $12^{\text {th }}$ centuries, indicate the existence of an elaborate and complex system of management for the monastic estates, directed to safeguard both the continuation of the monastic communities and the maintenance of their sacred edifices. ${ }^{35}$ The examination of relevant legal sources of "private law" in Central and Western Europe provides similar evidence regarding the concern of the monastic communities in relation to the protection and preservation of their sacred architectural structures and artifacts. ${ }^{36}$

Obviously, distinguishing between secular and sacred in the culture of the Middle Ages and the early Renaissance risks anachronism, imposing the values and divisions of modern mentalities upon thoughts and practices of the past. However, it is within this historical context and conceptual framework that the Church became not only a patron of the arts and artists, but also a dedicated supporter of the protection and enhancement of cultural heritage in globo. Indeed, the long and uninterrupted series of papal legislation for the protection of sacred monuments set the foundation for the "modern" approach of regulating artistic patrimony. ${ }^{37}$ Particularly the various acts promulgated during the $17^{\text {th }}$ century set strict laws against the intentional damage or theft of sacred antiquities, while the Papal Chirograph of October 1802 entitled La conservazione, became the basic law for the protection of all religious cultural property during this period. ${ }^{38}$ The Chirograph was revised in $1820,{ }^{39}$ but its principles remained unchanged until they were superseded by the laws of the United Kingdom of Italy after $1870 .{ }^{40}$ Similarly, the relevant Edict of Cardinal Pacca, regarding the inventory of all sacred and secular

34. Pertz G.H. (ed.), Monumenta Germaniae Historica, Vol. 1, Hanover, Legum, 1835, p. $91,149$.

35. See Konidaris I., Legal Aspects of the Monastic Typika, Athens, Ant. N. Sakkoulas, 2003.

36. See Smyruis K., "The Management of Monastic Estates. The Evidence of the Typika", Dumbarton Oaks Papers, Vol. 56, 2002, p. 245-261.

37. Schildgen B. D., Heritage or Heresy: Preservation and Destruction of Religious Art and Architecture in Europe, New York, Palgrave Macmillan, 2008, p. 173; LEVI D., "The Administration of Historical Heritage: the Italian Case", in Fisch S. (ed.), National Approaches to the Governance of Historical Heritage over Time. A Comparative Report [Cahier d'histoire de l'administration, Vol. 29, n 9, avril, 2008], p. 105 f.

38. Mariotti F., La legislazione delle Belle Arti, Roma, 1892, p. 226-233.

39. Ibid., p. 235-41.

40. Jokilento J., History of Architectural Conservation, Oxford, Butterworth-Heinemann, 1999, p. 75. - Wolf L., Kirche und Denkmalschutz: die päpstliche Gesetzgebung zum Schutz 
goods in the Pontifical State (issued on 7 April 1820), served as an inspiring model for the subsequent laws on securing religious cultural heritage drawn up in various European countries in the course of the $19^{\text {th }}$ century. ${ }^{41}$

It is common place that the $20^{\text {th }}$ century amidst the natural and cultural ruins left by several devastative armed conflicts gave birth to ecumenical agreements and international treaties intended to defend against human impulses to destroy or expropriate places of worship and sacral artifacts, ${ }^{42}$ such as the Hague Conventions on Land Warfare of 1899 and 1907, or the 1922/23 Hague Rules of Air Warfare (Art. 25). After the atrocities of the Second World War, the Fourth Geneva Convention (1949) reinforced the protection of "places of worship which constitute the cultural or spiritual heritage of peoples", ${ }^{43}$ while the great bulk of the subsequent statutes of the United Nations, the UNESCO and the Council of Europe, such as the provisions of the Hague Convention for the Protection of Cultural Property (1954), the World Heritage Convention (1972), the Convention for the Protection of the Architectural Heritage of Europe (1985), the European Convention on the Protection of the Archaeological Heritage (1969; revised in 1992), the European Landscape Convention (2000), and the European Convention on the Protection and Promotion of the Diversity of Cultural Expressions (2005), constitute major steps toward the international expansion of sacred patrimony, as a revered common heritage that surpasses national borders.

\section{FOSTERING THE SACRED HERITAGE "OF EUROPEAN SIGNIFICANCE"}

According to the Council of Europe's Framework Convention on the Value of Cultural Heritage for Society (signed in 2005; entered into force in 2011): "Valorisation of a cultural heritage through intercultural dialogue requires ongoing research and debate, especially to take account of disagreements which arise in the course of interpretation, for example when an ancient

der Kulturgüter bis zum Untergang des Kirchenstaates im Jahr 1870, Münster, Lit Verlag, 2003, p. $165 \mathrm{f}$.

41. Baldwin Brown G., The Care of Ancient Monuments: An Account of the Legislative and Other Measures Adopted in European Countries for Protecting Ancient Monuments and Objects and Scenes of Natural Beauty, and for Preserving the Aspect of Historical Cities, Cambridge University Press, 1905, p. 15 f.

42. SChildgen B. D., op. cit., p. 174.

43. UN Treaty 17512 in: United Nations, Treaty Series, Vol. 1125-1, 1979, p. 27. 
site is sacred to more than one religion". ${ }^{44}$ In the same vein, the Council of Europe has already issued a notable recommendation regarding the "Management of cathedrals and other major religious buildings in use", in order to encourage multi-level partnerships that will ensure the survival of such sacred spaces. ${ }^{45}$

At the EU level, the Treaty on the Functioning of the European Union (TFEU) requires the latter to take culture into account, in all its actions, so as to foster intercultural respect and promote diversity (Art. $167 \S 4$ ). In addition, specific provisions of the Treaty on European Union (TEU) stipulate that the Union, in view of "the cultural, religious [...] inheritance of Europe" (TEU, Preamble) "shall ensure that Europe's cultural heritage is safeguarded and enhanced" (TEU, Art. 3.3), while, pursuant to Article $167 \S 2$ of the TFEU, "Action by the Union shall be aimed at encouraging cooperation between Member States and, if necessary, supporting and supplementing their action in the $[\ldots]$ conservation and safeguarding of cultural heritage of European significance".

One should note that the aforementioned reference to the heritage of "European significance" encompasses not only the respective religious "national treasures possessing artistic, historic or archaeological value" (TFEU, Art. 36), but also the "religious rites, cultural traditions and regional heritage" (TFEU, Art. 13) that are considered important for the continuity of the spiritual "cultures and traditions of the peoples of Europe" (Charter of Fundamental Rights, Preamble). In this sense, the broadening of the concept of religious cultural heritage underlines the legal significance of its intangible elements as well, and shows that the aforesaid legislative approach is not mainly concerned with confined spaces or isolated objects, but rather with identifying and preserving the intangible notion of "sacredness" as a respected cultural value, representative of the pan-European (current or past) religious traditions. This is the case, for example, in reference to the economic activity in the Arctic region, in which "companies should operate with responsible caution especially in places [...] that are sacred to indigenous people". ${ }^{46}$ This is also the case in relation to the privileged spiritual and cultural status

44. Council of Europe Treaty Series (CETS) $n^{\circ}$ 199, Faro, 27.X.2005, Explanatory Report (notes under Art. 7).

45. Recommendation 1484 (2000) that was adopted by the Standing Committee, acting on behalf of the Assembly, on Nov. 9, 2000.

46. Opinion of the European Economic and Social Committee on EU Arctic Policy to address globally emerging interests in the region - A view of civil society, 17 Apr. 2013: OJEU C 198, 10.7.2013, p. 28. 
of the "avaton" regime of Mount Athos, which is acknowledged as an inaccessible and inviolable sacred peninsula ${ }^{47}$ pursuant to the Joint Declaration (No. 4) annexed to the Final Act of the Treaty of Accession of Greece to the European Communities. ${ }^{48}$ In both cases (i.e. the Arctic region and the Mount Athos region), the element of "sacred spatiality", albeit culturally diverse, is a reflection of the same heritage of "European significance". In other words, both sacred spaces, even though stemming from different spiritual traditions, are regarded "significant" parts of the same, varicoloured, vibrant and vast, European cultural inheritance.

\section{CURRENT LEGISLATIVE PATTERNS AT THE NATIONAL LEVEL}

Notwithstanding the existing international legal instruments and statutes, the respective European countries still legislate the protection of their "sacred" patrimony at the national level, as part of their unique spiritual and cultural wealth. Indeed, various projects and heritage conservation programs have been developed across the European continent, in accordance with national legislative provisions, locally-driven administrative actions and regional fiscal schemes. ${ }^{49}$ In this context, the regulation of sacred patrimony, along with its specific elements (monuments, sites and objects), remains primarily an issue of the respective States.

As it is self-evident, the cultural and linguistic diversity of the European continent, the individual variations of the national legal systems, the contrasting status of State-Church relations existing in each particular country, as well as the "ephemeral" nature of legislation, make it extremely difficult to provide a definitive account of the pertinent legislative patterns. Nevertheless, after surveying the plethora of national legislations on cultural heritage, it could be argued that there are three main legislative patterns, through which the element of "sacredness" may manifest itself:

(i) "sacredness" may be acknowledged as an additional, yet unique, attribute of specific places or objects, that fall within the ambit of general legal provisions (lex generalis). In this rationale, sacred places and sacred objects constitute, in essence, the subject of general civil law protection, as elements of cultural importance. This legislative pattern may be found, for instance,

47. Konidaris I., The Mount Athos Avaton, Athens, Ant. Sakkoulas, 2003.

48. OJEC L 291, 19.11.1979, p. 186. - See also Papastathis C., "The Regime of Mount Athos", in Ferrari S., Benzo A. (eds), op. cit., p. 287 f.

49. See Fornerod A. (ed.), Funding Religious Heritage, Farnahm, Ashgate, 2015. 
in Portugal (Act No. 107/2001, Art. 4), in Poland (Act of July 23, 2003, Art. 6 \& 3), in the Netherlands (Monumentenwet, Art. 1 e), or in Sweden (Heritage Conservation Act, Chap. 4). Similar provisions have been incorporated across the individual German States (Länder), in which the legal protection of sacred heritage entails the respect of both the spiritual and the social function of its various cultural aspects. ${ }^{50}$ In Austria, the protection of sacred heritage assets, balances on the principle of "including neutrality", ${ }^{, 1}$ and the need for co-operation between the State and the legally recognized owners of major cultural monuments, namely the recognized churches and religious societies. ${ }^{52}$ In Greece, in view of the relevant provisions of Act No. 3028/2002 "on the protection of antiquities and cultural heritage in general", any intervention in the vicinity of a religious monument must be compatible with its unique sacred nature. This is at its best exemplified by the relevant case-law, according to which the Court has protected the "sacred character" and "aesthetic value" of the Metropolitan Cathedral of Athens against the perilous expansion of subway construction works, ${ }^{53}$ as well as the historical significance of the Patmian Monastery of Saint John the Theologian against incompatible private constructions on the "sacred island" of Patmos. ${ }^{54}$

(ii) "sacredness" may justify the application of special rules of protection, particularly in cases of sites or places marked with an exceptional religious gravity and unique historical importance (lex specialis). For instance, in Greece, the Meteora monastic complex (where a network of cliff-top Byzantine monasteries has existed for centuries) has been protected since 1995 as an integrated "sacred area", pursuant to a special legislative framework, ${ }^{55}$ also in light of the Constitutional provisions of Art. 13 (religious freedom) and Art. 24 (protection of the cultural environment). Likewise, the sacred peninsula of Mount Athos, which is, in accordance with its ancient privileged status, "a self-governed part of the Greek State", ${ }^{56}$ is specifically protected

50. See Tsivolas T., Law and Religious Cultural Heritage in Europe, Heidelberg, Springer, 2014, p. 142-148.

51. Kalb H., Potz R., Schinkele B., Religionsrecht, Wien, WUV Universitätsverlag, 2003, p. $42-43$.

52. Wieshaider W., Denkmalschutzrecht. Eine systematische Darstellung für die österreichische Praxis, Wien, Springer, 2002, p. 135.

53. Council of State, decision $n^{\circ}$ 2073/1997.

54. Council of State, decision $n^{\circ} 457 / 2010$; see also Act No. 1155/1981 "Recognition of Patmos as a Sacred Island and other ecclesiastical issues".

55. Act No. 2351/1995 "Recognition of the Meteora area as a sacred site".

56. Greek Constitution, Art. $105 \S 1$. 
according to its own Constitutional Charter. ${ }^{57}$ Similar special attention has been paid also to other European sacred sites, such as the sacred mountain of Croagh Patrick (St Patrick) in Ireland, ${ }^{58}$ and the Isle of Iona on the western coast of Scotland, or other major pilgrimage sites, including Lourdes in the Pyrenees and Fatima in Portugal. ${ }^{59}$ Besides, in the same scheme of lex specialis, one could also add the various Concordats that have been signed, over the years, between the various States and the Catholic Church, regarding the maintenance and preservation of specific historical places of worship. For instance, according to the Agreement of 1984 between the Italian Republic and the Holy See (Accordo di Villa Madama), ${ }^{60}$ it has been acknowledged that "The Holy See shall retain the power to dispose of the Christian catacombs that exist underground at Rome and other parts of the Italian territory and $[\ldots]$ subject to the laws of the State [...] shall be at liberty to proceed with any necessary excavation and removal of sacred relics". ${ }^{61}$ Similar individual agreements between the religious and the local public authorities have been also established in Spain. ${ }^{62}$

(iii) "sacredness" may justify an exclusion from the general application of the pertinent legal provisions (without prejudice, of course, to mandatory provisions of national laws or jus cogens, e.g. the legislation on cultural heritage or environmental protection), because of its unique functional character, and, primarily, its direct relation to worship (privilegium). In Great Britain, for example, as far as listed buildings are concerned, official exemption from State control and relevant restrictions, is being provided (under specific conditions) for edifices in current use for worship. ${ }^{63}$ Whereas, in France, by virtue of the relevant provisions of the Act of 1905, ${ }^{64}$ as well as of the Act of 1907 concerning the public exercise of religion, ${ }^{65}$ the allocation (affectation légale) of the religious edifices that belong to the public domain (i.e. pre1905 structures) guarantees their prime destination and perpetual function

57. Konidaris I., Particular Religious Jurisdictions within the Greek Territory, Athens, Sakkoulas Publ., 2012, p. 192 f. - Tsivolas T., The Legal Protection of Religious Cultural Goods, Athens, Sakkoulas Publ., 2013, p. 176 f., 351.

58. See Tara Prospecting Ltd v. Minister for Energy [1993] Irish Law Reports Monthly, p. 771.

59. Tsivolas T., Law and Religious Cultural Heritage in Europe, op. cit., p. 75.

60. The agreement was ratified by Legge n. 121 del 25 marzo 1985.

61. International Legal Materials, Vol. 24, N. 6, 1985, p. 1589.

62. See Tsivolas T., Law and Religious Cultural Heritage in Europe, op. cit., p. 159-163.

63. Mynors C., Listed Buildings, Conservation Areas and Monuments, London, Sweet \& Maxwell, 2006, p. 553.

64. Loi du 9 décembre 1905 concernant la séparation des Églises et de l'État, Art. 13.

65. Loi du 2 janvier 1907 concernant l'exercice public des cultes, Art. 5. 
as places of worship. This legal "affectation", which is "gratuite, exclusive et perpétuelle", ${ }^{66}$ offers, through the allocation of the edifices to the public sphere, a solid legal basis for the effective protection against the possibility of insufficient maintenance or improper use and correlates, in practice, with both the cultural and the religious allocation (affectation culturelle et cultuelle) of the same sacred structures. ${ }^{67}$ Within this framework, any organized visit to a legally assigned place of worship depends upon the prior authorization of the competent religious authority; this privilege functions, in essence, as a right of veto indented, primarily, to protect the sacred dimension of such listed edifice. ${ }^{68}$

\section{EPILOGUE: TOWARDS THE STATUS OF RES MIXTAE}

It is true that "the sacred heritage is as varied as the human perception of the sacred". ${ }^{69}$ At the same time, the diversity and abundance of "sacred things" (res sacrae) and "sacred spaces" (loci sacri) that constitute the European religious cultural patrimony, stem from the various credos, dogmas and traditions of their respective faith communities. This crucial framework of religious law seems quite distant from the "mainstream" way of understanding cultural heritage in association with national laws and international statutes. In other words, these products of "sacredness", being in essence mediums of worship, are located at the very heart of the autonomy and freedom of internal management of the respective religious organizations from which they stem. Therefore, "given that the protection of sacred places stems from freedom of religion, religious law and tradition play a fundamental role that cannot be neglected when defining the nature of a sacred place", or of a sacred object for that matter. ${ }^{70}$

Having said the above, the right of each faith community to regulate and administer its cultural property sui iuris, may be limited by the secular laws

66. Benelbaz C., Le principe de laïcité en droit public français, Paris, L'Harmattan, 2011, p. 475.

67. See Fornerod A., Le régime juridique du patrimoine religieux, Paris, L'Harmattan, 2013, p. 39 f., $155 \mathrm{f}$.

68. See CE, 4 Nov. 1994, No 135842, Abbé Chalumey; CE, ord. 25 Aug. 2005, No 284307, Commune de Massat, where the relevant privilege was extended also to non-religious uses of listed places of worship.

69. CHECHI A., "Sacred Heritage in Cyprus: Bolstering Protection through the Implementation of International Law Standards and the Adoption of an Object Oriented Approach", in Ferrari S., Benzo A. (eds), op. cit., p. 302.

70. Benzo A., op. cit., p. 23. 
governing the maintenance and upkeep of the same property, as part of a broader national heritage. Indeed, the same "sacred" objects and places of worship may be subject to an organized system of State control, under the scheme of one of the aforementioned three-dimensional legislative patterns (lex generalis, lex specialis, privilegium). This, in effect, means that, within the ambit of the State's heritage policy and legislation, may belong all the sacred assets which are deemed to be of national (or international) importance, ranging from simple burial sites to great monastic complexes and cathedrals, as integral parts of a wider heritage network. In light of this, and in order to strike a balance between the demands of the public interest and the necessary protection of fundamental religious rights, the best possible approach here would be that of defining all these ambiguous cultural elements, as res mixtae. ${ }^{71}$ The term reflects the complexity and importance of these elements and, at the same time, signifies the need for co-operation between the States of Europe and the faith communities, as well as the right of the latter to retain their religious identity, tradition and values; being more than just a vague structure, this particular approach provides the necessary legal foundation for the proper understanding and regulating of the various aspects of the sacred heritage "of European significance" (TFEU, Art. 167 $\S 2$ ); in essence, this approach combines the public function (offentliche Funktion) with the potential liturgical function (liturgische Funktion) of the various "sacred" elements of religious heritage. ${ }^{72}$ In this way, the European states respect both the autonomy of the respective faith communities and the secular values of our modern-day liberal democratic societies, while acknowledging the notion of "sacredness" as an underlying value of the exquisite cultural heritage that emanates from the different religious traditions of the peoples of Europe.

71. Regarding the consensus model of res mixtae, which stems from the German approach on Constitutional Law of State-church relations (Staatskirchenrecht), and corresponds to the status of "gemeinsame Angelegenheiten" (issues of common interest), where the public responsibility of the State is coordinated with the autonomous activity of the respective religious communities. See Von Campenhausen A. F., De Wall H., Staatskirchenrecht. Eine systematische Darstellung des Religionsverfassungsrechts in Deutschland und Europa, München, C. H. Beck, 2006, p. 52 f.; Tsivolas T., Law and Religious Cultural Heritage in Europe, op. cit., p. $103 \mathrm{f}$.

72. HeCKel M., Staat, Kirche, Kunst: Rechtsfragen kirchlicher Kulturdenkmäler, Tübingen, Mohr, 1968, p. 242-243. 